\title{
EXPLORING CORPORATE RESPONSIBILITY IN OMAN - SOCIAL EXPECTATIONS AND PRACTICE
}

Flora Minnee

Curtin University, School of Marketing, GPO Box U1987, Perth Western Australia 6845

Email: Flora.Minnee@cbs.curtin.edu.au

Tel: +61 892662839 Fax: + 61892663937

Tekle Shanka *

Curtin University, School of Marketing, GPO Box U1987, Perth Western Australia 6845

Email: Tekle.Shanka@cbs.curtin.edu.au

Tel: +61 892662839 Fax: + 61892663937

Ruth Taylor

Curtin University, School of Management, GPO Box U1987, Perth Western Australia 6845

Email: Ruth.Taylor@cbs.curtin.edu.au

Tel: +61 892662287 Fax: + 61892667987

Brian Handley

Curtin University, School of Marketing, GPO Box U1987, Perth Western Australia 6845

Email: Brian.Handley@cbs.curtin.edu.au

Tel: +61 892664389 Fax: + 61892663937 


\title{
EXPLORING CORPORATE RESPONSIBILITY IN OMAN - SOCIAL EXPECTATIONS AND PRACTICE
}

\begin{abstract}
Purpose - This paper explores social expectations and practice of Corporate Social Responsibility (CSR) in Oman.

Design/methodology/approach - In this study, 153 respondents (45\% Omanis and 55\% expatriates) shared their expectations which were compared with documentary evidence from core large and medium-sized enterprises CSR practice in Oman.

Findings - On average CSR mean scores exhibited similarity for most respondent groups except for Omanis, young people, and those with high school or lower education who scored less indicating a general lack of awareness of CSR. Society in Oman seems to expect corporations to provide 'safe and reliable products/services', 'appropriately treat employees', 'behave ethically', and be 'committed to social responsibility'.

Research limitations/implications - While there is limited generalizability of the findings of this exploratory study per se due to sample size limitations, a clear pattern emerges to facilitate more in-depth studies on CSR in Oman, and furthermore in other emerging market economies and transitional economies.

Practical implications - The study demonstrates a need for additional research into CSR awareness, philosophy and practice in the small and medium enterprise sectors, and other industry sectors.

Originality/value - The paper presents findings from an exploratory empirical study investigating social expectations of CSR in Oman, and highlights the practice of CSR in Oman. It also compares these findings and other studies' on the philosophy, nature and practice of CSR in emerging market and transitional economies.
\end{abstract}

Keywords Corporate Social Responsibility, Oman, sustainable development, transnational and multinational corporations, emerging market and transitional economies

Paper type Research paper. 


\section{Introduction}

The philosophy and practice of corporate social responsibility (CSR) has been examined from a variety of perspectives in several empirical studies. Research findings show that CSR relates to social expectations of business and how business responds to such expectations (Imbun, 2007, Jamali and Mirshak, 2007; Roberts et al., 2007; Amaeshi et al., 2006; Eweje, 2006; Mohan, 2006); the transitional economy (Koladkiewicz, 2009; Szczepanski et al., 2009; Brady, 2005), and the global perspective (Oppenheim et al., 2007, Environics International, 1999). Whitehouse's (2006) study of CSR in the United Kingdom suggests two core components of CSR include philanthropy concerning charitable donations or more broadly, identifying and responding to stakeholder concerns.

Generally, definitions and social expectations of CSR in many empirical studies (Koladkiewicz, 2009; Szczepanski et al., 2009; Imbun, 2007; Jamali and Mirshak, 2007; Oppenheim et al., 2007; Amaeshi et al., 2006; Eweje, 2006; Mohan, 2006; Brady 2005; Environics International, 1999) indicate that social expectations of corporations overtime in any one place are due to a variety of universal drivers such as "local needs (community expectations)/public pressures, globalisation (including transnational and multinational influences), competition, public relations (branding), regulation, and a firm's success" (Amaeshi et al., 2006: 94). Internal drivers for CSR include "a concern to 'do the right thing', to retain customers and to motivate employees" (Whitehouse, 2006: 294). External drivers are the secondary stakeholders such as non-governmental organisations (NGOs) and the socially responsible investment (SRI) community. Depending on the industry sector, Whitehouse (2006) suggests that these groups can potentially significantly impact on corporate reputation and profitability.

Ideally, CSR should be "a business way of life which does not advocate altruistic sacrifice but responsible profit-generation, benefiting owners, employees, customers, the community and the environment alike" (Tan, 2005:6). Thus, good CSR or good 'corporate citizenship' involves "making sure that the programs [invested] in fit with [corporate] business, achieving real business-oriented goals, as well as societal ones, and engaging employees and customers" (GolinHarris, 2005). Therefore, CSR can be identified as being primarily a business strategy for the pursuit of profit maximization, or preventing loss of profits attributable to secondary stakeholder activism with the interests of employees, consumers and the environment as secondary goals (Trebeck, 2008; Whitehouse, 2006).

However, such a business strategy often implies a tri-sector partnership of government, private enterprise and society for successful CSR practice (Koladkiewicz, 2009; Szczepanski et al., 2009; Eweje, 2006). In this sense, corporate social responsibility becomes linked with sustainable development (SD) and economic (corporate) sustainability, in particular, in non-Western parts of the world (Steurer et al., 2005; Eweje, 2006). Steurer et al. (2005) presented a comprehensive framework of sustainable development - economic, social, environmental, and second-order requirements - on the microeconomic level. Whilst there is much discussion concerning the specific meanings of sustainable development, it is widely accepted as being that which "meets the needs of current generations without compromising the ability of future generations to meet their needs and aspirations" (WCED, 1987:43 cited in Steurer et al., 2005). Sustainable development requires "the integration of economic, social and environmental issues in all societal spheres and levels in the short- and long-term" (Steurer et al., 2005: 264). When considered from a corporate perspective, SD revolves around either environmental (conservation and efficient 
management) and social policies (social welfare of the society and individuals), or management systems such as EMAS, ISO 14001, or SA 8000 (Steurer et al., 2005). Economic (corporate) sustainability, particularly in a developing country context, often revolves around legitimacy of continued operations and profitability, stakeholder power, and social issue life cycles (Royal Dutch Shell, 2008; Eweje, 2006).

CSR will tend to be perceived more as a public relations strategy, but also as philanthropy and altruism in developing countries (Imbun, 2007; Amaeshi et al., 2006; Eweje, 2006; Globescan 2001; Environics International, 1999) and transitional economies (Szczepanski et al., 2009; Koladkiewicz, 2009; Brady 2005). Such CSR perceptions and practice are a function of the "level of awareness or level of assimilation of the [...] construct" (Amaeshi et al., 2006: 93). Socioeconomic, socio-political and local cultures are key elements in the definition and practice of CSR, in particular in developing countries (Amaeshi et al., 2006) and transitional economy contexts (Koladkiewicz, 2009; Szczepanski et al., 2009). However, research indicates that there remains a high level of unawareness of both the concept and practice of CSR (Koladkiewicz, 2009; Whitehouse, 2006).

It is assumed that the "very largest companies, particularly extraction companies [...] FTSE companies' are the best CSR practitioners as 'the most socially aware' of the concept" (Knox et al., 2005: 20). Furthermore, assuming that "size discriminates between sophisticated and embryonic CSR practices, one might conclude that the CSR practices of small and medium-sized enterprises [SMEs] are likely to be weak" (Knox et al., 2005: 20).

Oman's economy, like that of Nigeria, South Africa, and Papua New Guinea is primarily dependent on the extractive industry (Imbun, 2007; Amaeshi et al., 2006; Eweje, 2006). The most important extractive industry player there (albeit as joint venture partner with the government) is Shell, a FTSE listed company.

Given all the above factors, this study explores the concept and practice of CSR in Oman by the key extractive industry player as well as a business from the SMEs sector.

\section{CSR and the Sultanate of Oman}

Oman is an Islamic emerging economy whose government pursues a socio-economic development strategy in which the private sector and civil society organisations are expected to work in partnership with the government to ensure national competitiveness and social equality (Abdulnabi Macki, 2007; Halfway to Vision 2020, 2007; Toky, 2007; Ministry of Information, 2004; Chamber Oman, 2002). It is a mixed market economy that is primarily dependent on the energy (oil and gas) sector and characterized by minority joint ventures with multinational corporations (MNCs) and transnational corporations (TNCs) (Ministry of Information, 2004; Chamber Oman, 2002). There are also associated small and medium-sized service companies with increasing local capability (Abdulnabi Macki, 2007; Halfway to Vision 2020, 2007; Toky, 2007; Ministry of Information, 2004; Chamber Oman, 2002). Such private sector partners are expected to work with the Omani government and other social actors to meet local needs, for example poverty alleviation which is outlined in the national socio-economic development plan, the $2^{\text {nd }}$ Long Term Development Strategy (1996-2020) for Oman ('Vision 2020') and subsequent planning (Abdulnabi Macki, 2007; Halfway to Vision 2020, 2007; Toky, 2007; Ministry of Information, 2004; Chamber Oman, 2002). 
A major need that has been identified locally, aimed at fostering national competitiveness and socio-economic development, is the employment and training of locals (formalized as the 'Omanisation Policy'), and technological transfer (Abdulnabi Macki, 2007; Halfway to Vision 2020, 2007; Toky, 2007; Ministry of Information, 2004; Chamber Oman, 2002). In Oman, as in most Moslem countries, philanthropy and altruism, in particular to the less privileged in society, guides social interactions at all times, but especially during the religious period of Ramadan. Indeed, Islam has been positively correlated with the philosophy and practice of CSR (Zinkin, 2007). Whilst, CSR philosophy and practice in emerging economies tends to be primarily characterized as philanthropy and altruism (Koladkiewicz, 2009; Szczepanski et al., 2009; Imbun, 2007; Amaeshi et al., 2006; Eweje, 2006; Globescan 2001; Environics International, 1999), there is scope to understand this concept further within cultural, religious and societal frames.

\section{Method}

This research project adopted a two-phase research approach to investigate CSR in Oman. Part A of the project utilised a quantitative research study to investigate CSR, whilst Part B adopted a secondary research approach to investigate CSR in MNEs in Oman. The quantitative study adopted a non-probability quota sampling method due to the exploratory nature of the study (Sudman, 1980 cited in Malhotra et al., 1996). The objectives of the study were:

- determine the nature of and practice of Corporate Social Responsibility (CSR)/Corporate Citizenship (CC) by eliciting the opinions and perceptions of consumers in Muscat, Oman;

- determine which definition of CSR/CC the target sample subscribes to by identifying what they understand to be the role of companies;

- identify what factors (CSR or non-CSR) they find influential in forming impressions of companies;

- assess their behaviour toward socially irresponsible companies;

- determine through segmentation analysis the expectations and perceptions regarding $\mathrm{CSR} / \mathrm{CC}$;

- determine what role media and technology play in informing consumers about companies CSR practice;

- determine to what extent the findings of previous empirical studies referred to in this study are applicable to Oman.

A field survey involving a representative target sample of 400, derived from the 2003 Oman census data, (see Table 1) screened by nationality (Omanis and expatriates), age (18 and above) and knowledge of CSR, in the Greater Muscat area of the Sultanate of Oman was conducted. The additional factors of 'gender' and 'education' as well as further differentiation of the 'expatriates' were employed for data analysis. Appropriate quota procedures and weighting are suggested as helping reduce selection bias / survey error (Sudman, 1980). 
Data for the current study and the Shanka et al., (2008) paper was derived from the original CSR in Oman study's (Minnee, 2007) data set, $\mathrm{N}=153$ of the projected target sample of 400 respondents (see Table 1). Respondents were asked to voluntarily complete a self-reporting questionnaire. This was undertaken with the assistance of associated guide cards (see Appendix 2) to indicate the degree of importance they attributed to each of several factors (see Figure 1.1) when rating a company for corporate social responsibility. The attributes list (see Figure 1.1 and Appendix 1) was adapted from prior CSR research (GolinHarris, 2005)

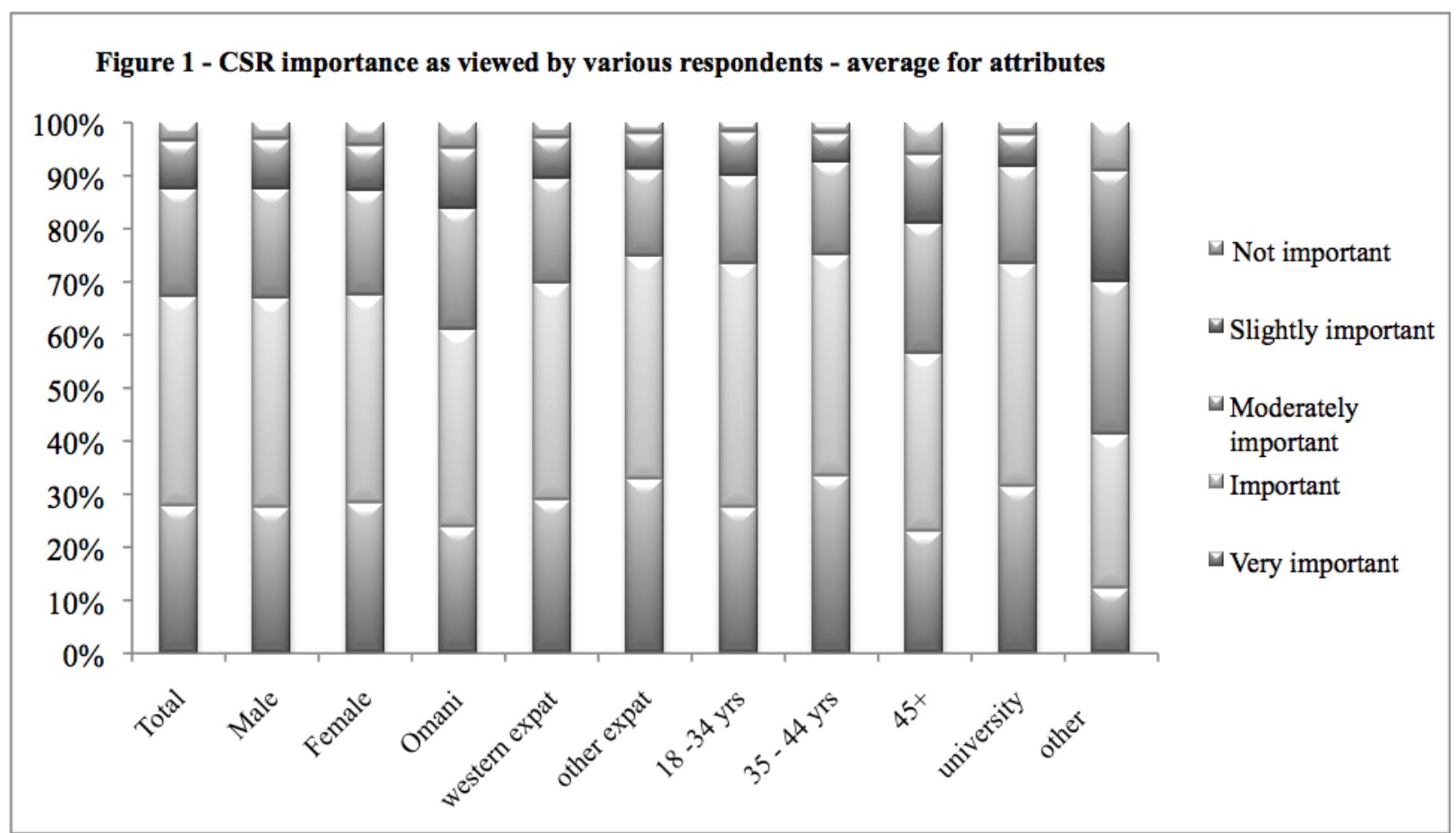

\section{Findings}

Data collected from the fieldwork was statistically analysed using the Statistical Package for Social Sciences (SPSS). The study respondents (see Figure 1) consisted of 153 respondents $(\mathrm{N}=153)$ aged 18 years and above who had to be aware or knowledgeable of the concept of CSR. Respondents were 69 (45\%) Omanis and 84 (55\%) expatriates. The expatriates were grouped into 'Western expatriates' $(\mathrm{N}=40)$ (Europeans, North and South Americans, and Australasians) and 'Other expatriates' ( $\mathrm{N}=44$ ) ('other expats' in Figure 1) comprising South Asians, other Middle Easterners, East Asians, and Africans. Differences among the various categories of expatriates were not explored as part of the study. Data analysis procedures included Analysis of Variance (ANOVA) on age (18-34 years; 35-44 years and 45+). Respondents were also compared using the Independent t-test procedure on age (18-34; 35-44, and over 45 years), gender (male and female), and level of education attained (university degree or higher, high school or lower). The respondent sample comprised majority of males $(\mathrm{N}=99)$ and one-third females $(\mathrm{N}=54)$. The vast majority of the respondents reported $(\mathrm{N}=123)$ that they had achieved a university level education, 
with the remainder of the respondents $(\mathrm{N}=30)$ having high school or lower educational qualifications. The largest respondent group was aged between 18-34 years $(\mathrm{N}=61)$, followed by those aged $35-44(\mathrm{~N}=54)$, and $\mathrm{N}=36$ being above 45 years old. Overall, the following six attributes were found to be important. The respondents identified 'safe products/services', appropriate 'treatment of employees', provision of 'reliable products/services', 'environmental protection', 'ethically responsible', and committed to 'social responsibility' (see Figure 1.1).

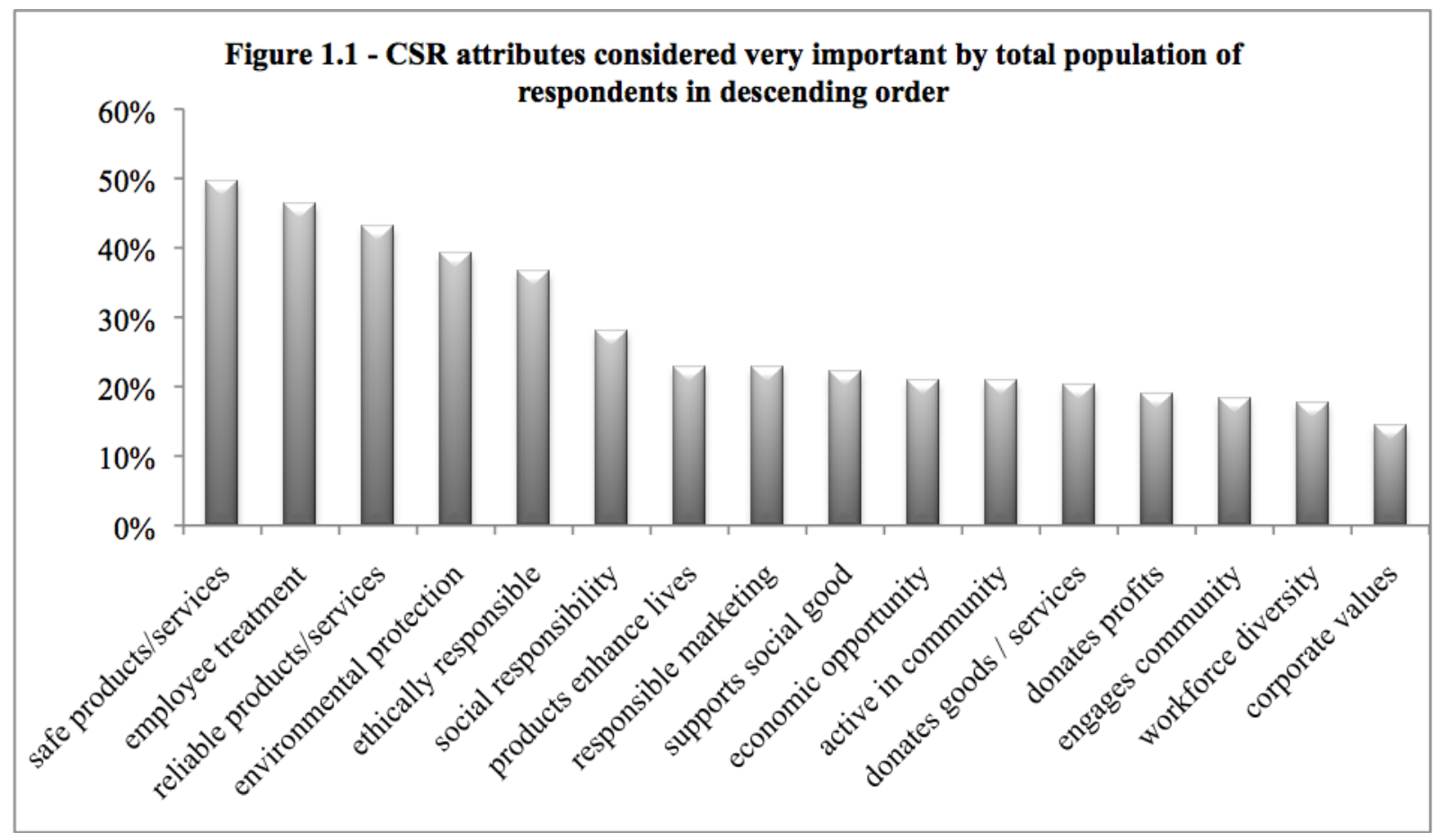

\section{Results and discussion}

The 16-item attributes measured on 5-point Likert scale show significant positive correlations ranging from 0.79 to 0.17 , with an internal consistency alpha $(\alpha)$ of 0.91 . Factorability of the 16 attributes was determined by an adequate KMO measure of sampling adequacy (MSA) value of 0.856 using Principal Components with Varimax rotation, Eigen value $>1$ and factor loading of 0.45 as criteria. The 16 attributes were represented by three components, namely, community (Comp1), organisation (Comp2), and commitment (Comp 3) and explained 62\% of total variance (see Table 1). Significant differences were noted on three demographic variables, namely, age, education, and nationality, but not gender (Shanka et al., 2008). The implications are that more mature persons and those with college or higher education qualifications would more likely rate all components (and by implication the attribute variables) higher compared with younger age or lower educated individuals. 
Table 1: Rotated Component Matrix* of Attributes

\begin{tabular}{|c|c|c|c|c|}
\hline Attributes & $\begin{array}{c}\text { Mean } \\
\text { scores* }\end{array}$ & Community & Organisation & Commitment \\
\hline $\begin{array}{l}\text { Donates/invests fair share of profits to benefit } \\
\text { others }\end{array}$ & 3.52 & .812 & & \\
\hline $\begin{array}{l}\text { Donates/invests fair goods/services to benefit } \\
\text { others }\end{array}$ & 3.59 & .781 & & \\
\hline $\begin{array}{l}\text { Corporate values are aligned with those of } \\
\text { society }\end{array}$ & 3.59 & .724 & & \\
\hline $\begin{array}{l}\text { Actively involved in communities where it does } \\
\text { business }\end{array}$ & 3.66 & .643 & & \\
\hline Products/services enhance peoples' lives & 3.71 & .605 & & \\
\hline Supports a cause/issue leading to social good & 3.62 & .565 & & \\
\hline Engages community in local business decisions & 3.41 & .563 & & .460 \\
\hline Committed to social responsibility & 3.89 & .473 & & \\
\hline Reliable products/services & 4.15 & & .877 & \\
\hline Safe products/services & 4.24 & & .861 & \\
\hline Employee treatment & 4.18 & & .731 & \\
\hline Behaves ethically & 4.08 & & .641 & \\
\hline Responsibly markets its products/services & 3.75 & & .583 & \\
\hline Committed to workforce diversity & 3.55 & & & .831 \\
\hline Committed to environmental protection & 3.93 & & & .727 \\
\hline Committed to economic opportunity & 3.67 & & & .483 \\
\hline Eigen value & & 6.677 & 2.040 & 1.206 \\
\hline Explained variance \% & & 41.73 & 12.75 & 7.54 \\
\hline Cronbach alpha $(a)$ & & .868 & .863 & .740 \\
\hline
\end{tabular}

*KMO MSA = .856; Principal Components with Varimax Rotation; Cronbach alpha=.91;

$* 1=$ not important, $5=$ very important

\section{CSR expectations and practice in Oman and elsewhere}

As Table 1 shows, the findings reporting the respondents' expectations of the role of business in society appear to parallel those reported in studies in several other parts of the world (Das, 2009; Koladkiewicz, 2009; Minnee, 2007; Eweje, 2006; GolinHarris, 2005). Slightly more respondents (86\%) in the Minnee (2007) study 'agree' that 'the role of a company in society should be focus on making profit, paying taxes, and providing employment in ways that obey the law' than do $(53 \%)$ that it should 'do all this in ways that set higher ethical standards, going beyond what is required by law.'

A review of Table 1 indicates that the top five important attributes were: 'safe products/services' (4.24), 'employee treatment' (4.18), 'reliable products/services' (4.15), 'behaving ethically' (4.08), and 'committed to social responsibility' (3.89). Most of the attributes loaded on component 1 - community. Factors dealing with organisation's internal resources such as employees, products or services loaded on component 2 - organisation. Finally, 'committed to environmental protection' (3.93), 'committed to economic opportunity' (3.67), and 'committed to workforce diversity' (3.55) all loaded on component 3 - commitment. When these findings were compared to other research findings, it is noted that in Poland (Dziopa, 2002:10-13; Responsible 
Business Forum, 2002:8 cited in Koladkiewicz, 2009) respondents' expect appropriate 'employee treatment' by businesses. In the Indian context, three proposed CSR models relate to 'business involvement in community development', 'socially responsible products and services', and 'socially responsible employee treatment' (Das, 2009). Eweje (2006: 93-94) suggests that Nigerians and South Africans expect Multinational Enterprises (MNEs) in the extractive industry (oil and mining) sector to meet locally defined social and economic goals. Such a stance focuses primarily on items in component 1 - community and to a lesser extent component 3 commitment (Eweje, 2006). The findings reported from another study (Amaeshi et al., 2006), also confirm that CSR in Nigeria is perceived and practiced as philanthropy.

\section{CSR in Oman as philanthropy and/or strategic systematic CSR}

This section explores CSR practice in Oman to determine if it matches social expectations as suggested in prior empirical CSR studies in Oman (Minnee, 2007; Shanka, et al., 2008). Several studies (Das, 2009; Koladkiewicz, 2009; Amaeshi et al., 2006; Eweje, 2006; Whitehouse, 2006) have used documentary (online and paper-based) evidence to explore corporate CSR policies and practice. Past studies suggest that as an Islamic (Zinkin, 2007) emerging market economy (Koladkiewicz, 2009; Imbun, 2007; Amaeshi et al., 2006; Eweje, 2006; Globescan, 2001; Environics International, 1999), CSR practice in Oman will be predominantly 'CSR as philanthropy'. Indeed, findings of CSR studies (Imbun, 2007; Amaeshi et al., 2006; Eweje, 2006) of emerging market companies with economies based primarily on natural resources, such as the economy of Oman, appear to conform to definitions of CSR as philanthropy in practice.

However, some of the five most important attributes identified by study respondents (Minnee, 2007) go beyond non-core corporate strategy 'CSR as philanthropy-related' ones (Koladkiewicz, 2009; Szczepanski et al., 2009; Shanka, et al., 2008; Whitehouse, 2006) for example 'donates/invests fair share of profits to benefit others' (3.52) and 'donates/invests fair goods/services to benefit others' (3.59), and public relations associated 'supports a cause / issue leading to social good' (3.62).

\section{CSR versus Philanthropy}

In the early 1900's, as a result of significant criticism, corporations commenced giving donations to charitable organisations in an attempt to improve their public relations image (Wulfson, 2001). However not everyone agreed (Friedman and Friedman, 1962: 133) stated that "corporate officials are in no position to determine the relative urgency of social problems." Friedman contended that businesses should "produce goods and services efficiently and leave the solution of social problems to concerned individuals and government agencies" suggesting that money made by corporations should be returned to shareholders. However in more recent time Freemans (1984) 'stakeholder theory' challenges this view positing that it is beneficial for a company to engage in certain CSR activities, with Donaldson and Preston (1995) expanding this theory by stressing that moral and ethical components of CSR are reasons for engaging in such philanthropic activity. Whilst CSR may initially have been about "the scope of the responsibility of companies towards their environment" (De Schutter 2008: 203), in recent years this has gone "beyond compliance to engage in actions that further some social good beyond the interest of the firm" (McWilliams et al., 2006: 1). In some cases community goals have been advanced by corporations providing financial assistance (McWilliams, et al., 2006) or have seen the inclusion of social characteristics or features into products, for example in 1990 the H. J. Heinz company 
adopted a 'dolphin safe' policy at the insistence of environmental and consumer groups (Wulfson, 2001). Some organisations such as Microsoft have donated millions of dollars of software, licenses and grants to educational institutions (Wulfson, 2001) however there are critics who contend that these donations have an ulterior motive in that they benefit Microsoft by allowing the company access to market more Microsoft products. Additionally, in more recent times wealthy philanthropists such as Ted Turner, Bill and Melinda Gates and Warren Buffet set up foundations considering that large personal fortunes should be used to better societies.

Amaeshi et al. (2006) explored CSR philosophy and practice in local Nigerian companies and suggested that CSR there is philanthropy because of socio-cultural, socio-economic and sociopolitical factors. Eweje (2006) focused on social investments and the role of multinational enterprises (MNCs) as partners to social development with local communities and other stakeholders in South Africa and Nigeria. Imbun (2007) explored corporate philanthropy and multinational mining companies' relationships with local host communities. Szczepanski et al. (2009) and Koladkiewicz (2009) examined practice by MNCs and local small and medium enterprises (SMEs), and suggested that the latter practiced philanthropy more due to a greater lack of CSR awareness.

There is some evidence that CSR philosophy and practice in Oman is either philanthropy or philanthropy mixed in with systematic broad-based CSR incorporating the economic, society and the environment, depending on the industry sector concerned. For instance, every year during the Holy Month of Ramadan, major players in the Omani telecommunications sector individually or in alliance with one or several large local banks as well as the greater citizenry (corporate or otherwise) embark on major charity drives. They then make in kind or in cash donations, often to less privileged local children and communities to facilitate celebrating the post-Ramadan Eid celebrations. Socio-culturally, it is the expected practice during this religious period for all Moslems. This is similar to findings in a study investigating CSR philosophy and practice by indigenous firms in Nigeria (Amaeshi et al., 2006) and one on CSR in Poland (Szczepanski et al., 2009). According to Ansari, "every individual is born with three debts, which he must repay in his lifetime - debts to parents, society and environment" (Jose, 2008). Additionally, by listing his company's un-structured CSR policies and practices, identified it as being predominantly philanthropy (Jose, 2008). He revealed that CSR practice in Oman is voluntary for corporations who are not obliged to have a CSR policy (Jose, 2008). However, Jose (2008) added that the "Al Ansari Group holds regular blood donation camps [...] once a month [...] hold free medical camps [...] for employees and people from neighbouring camps, joined the disaster relief after Cyclone Gonu devastated Oman in 2007, gives aid to the needy, sponsors cultural programmes or entertainment shows, [makes monetary donations, hosts religious meets]".

As to their employees, the Al Ansari Group is resolving housing problems by building and providing fully furnished corporate housing (Jose, 2008). Employees also receive corporatesubsidized life insurance coverage in addition to the legally mandated work insurance (Jose, 2008). There are on-going talks with medical institutes in India where employees can undertake a bi-annually complete medical check-up (Jose, 2009). Appropriate 'employee treatment' is considered strategic CSR, and is rated as a highly important attribute by consumers (Koladkiewicz, 2009; Shanka et al., 2008; GolinHarris, 2005; Globescan, 2001; Environics International, 1999). 
The CSR philosophy and practice of the Omani government's primary joint venture partners, the natural resource sector MNCs and transnational actors appear consistent with that in other emerging economies with similar economic structures (Imbun, 2007; Eweje, 2006). Society at any given point in time has economic, social and environmental needs that they expect transnational and multinational enterprises operating and impacting their communities to meet (Imbun, 2007; Eweje, 2006). Oman is largely dependent on the oil and gas industry sectors that still represent the bulk of the Gross Domestic Product (Abdulnabi Macki, 2007; Halfway to Vision 2020, 2007; Toky, 2007; Ministry of Information, 2004; Chamber Oman, 2002). Corporations, generally minority joint venture partners of the Omani government, in the same oil and gas industry sectors are among the best employers, trainers, and creators of new servicerelated businesses in Oman (PDO, 2007a). These corporations also possess the expertise and technology sought by Oman in its pursuit of a knowledge-based and technological advanced competitive market economy.

The core oil and gas, and related services player in Oman is Royal Dutch Shell PLC (Shell). In Oman that means, Shell Development Oman LLC and its partners in Oman - Petroleum Development Oman (PDO), Oman LNG, Qalhat LNG and Shell Oman Marketing (Shell, 2008a). Oman is considered one of Shell's 'heartlands' - "core countries that have the available infrastructure, expertise and remaining growth potential for Shell to sustain strong operational performance and support continued investment" (Shell, 2008b). Shell Development Oman LLC and these partner organisations advocate a Royal Dutch Shell PLC sustainable development business strategy to operations and its impacts on society and the environment (Shell, 2008b, 2008c; PDO 2005; and PDO, 2007). Royal Dutch Shell LLC's commitment to contribute to sustainable development (SD) entails "balancing short and long tern interests, integrating economic, environmental and social considerations into business decision-making" (Shell, 2007c). Alongside the SD commitment is Shell's Health, Safety and Environment (HSE) policy and commitment and supporting standards, that "set common expectations and mandatory requirements across Shell" (Shell, 2007d). The associated standards are minimum health management standards, security standard, standard for ship quality assurance, diversity and inclusiveness commitment, minimum environmental standards, animal testing standard, biodiversity standard, and climate change commitment (Shell, 2007d).

\section{Addressing society-identified needs in Oman}

In Oman identified needs include capacity building through the employment and appropriate training of nationals ('Omanisation Policy') to replace overdependence on expatriate labour while building for future socio-economic growth and international competitiveness (Abdulnabi Macki, 2007; Halfway to Vision 2020, 2007; Toky, 2007; Ministry of Information, 2004; Chamber Oman, 2002). Thus, PDO ensures the provision of safe as well as reliable products and services for the nation and external customers (including during 2007's tropical storm, Gonu) while employing and providing appropriate training and work-related bonuses and packages for Omanis (PDO, 2007a). Therefore, the joint ventures address identified local needs as well as several CSR attributes highlighted as important by study respondents (Shanka et al., 2008; Abdulnabi Macki, 2007; Halfway to Vision 2020, 2007; PDO, 2007a; Toky, 2007; Ministry of Information, 2004; Chamber Oman, 2002). The identified local needs include having a stable national income, employment and appropriate training of Omani youth, male and female as well as safe and consistent products/services. Respondents also highly value 'behaving ethically', and 'committed to social responsibility' (cf. Shanka et al., 2008). The key here is that society's needs are 
identified through active stakeholder engagement between Shell, its joint ventures and representatives of Oman's (national and local) government, concession area and other local communities, civil society organisations, and so forth (Shell a, 2008; PDO, 2007a; PDO, 2005).

Within PDO, there is a formal Social Investment Committee with high level government officials from the Ministries of National Economy, Interior, Oil and Gas, and three senior staff representatives of PDO that oversees all SI projects from proposal to completion and delivery (PDO, 2005). It has been suggested in a CSR study (Eweje, 2006) on MNCs as partners to social development that Shell's problems in Nigeria's Niger Delta area of operations is partly due to a lack of dialogue/engagement with local communities there. Shell supposedly implemented social investment projects, but without consulting locals on their actual needs, or was perceived as not having done enough (Eweje, 2006). Appropriate "employee treatment as well as the necessary education, scholarships and training for Omanis to fill those jobs" would be beneficial to businesses adopting CSR. Other attributes relating to the environment, cause-related marketing, community involvement, community dialogue, workforce diversity, economic opportunity, responsible product/services marketing, and products/services enhancing peoples' lives were also rated as important, albeit to a lesser degree (Shanka et al., 2008). In emerging market economies and transitional ones, education and training schemes are some of the CSR tools of choice (Eweje, 2006; Szczepanski et al., 2009).

Shell Development Oman runs several highly popular and successful training programmes solely or jointly with local businesses targeting Omani youth. An example is the Intilaaqah programme aimed at stimulating unemployed Omani youth into becoming entrepreneurs (Shell, 2008a; Shell, 2009d). Then, there is the Intilaaqah Enterprise Fund that offers business development as well as financial support to small and medium-sized enterprises (Shell, 2009d). Yet another is the Women Career Development Programme ( $\left.\mathrm{La} \mathrm{k}^{\prime} \mathrm{k}\right)$ run in association with a local management consultancy to empower middle-aged women through specialised learning and development workshops exploring and imparting relevant social and work-related knowledge (Oman Daily Observer, 2009b). In 1974, 71\% of PDO's 1,721 employees were Omani, and in 2007, 78\% of the over 5,000 employees are Omanis (PDO, 2007b). Of the 815 PDO senior staff in 2007, 361 were Omanis compared to 67 out of 264 in 1974 (PDO, 2007b). While only two PDO Omani staff held PhDs in 1974, there were over 90 of those as at 2007 (PDO, 2007b). Shell Technology Oman, a regional Enhanced Oil Recovery (EOR) hub, was established to work with PDO and the Oil and Gas Research Centre of Oman's Sultan Qaboos University focusing on thermal and chemical EOR (Shell, 2008b). The three main EOR technologies - thermal, chemical and miscible gas - are essential to oil recovery from several older PDO oil fields (Shell, 2008b).

In 2007, PDO signed 11 Memoranda of Understanding (MOUs) with various Omani government ministries on a variety of social initiatives - education, training, health and environment - aimed at positively contributing to Omani society (PDO, 2007a). Such a range of social investment for socio-economic development is consistent with similar ones identified in South Africa and Nigeria' as well as in Poland (Szczepanski et al, 2009; Eweje, 2006). PDO also engaged in Social Investment (SI) projects aimed at reviving threatened Omani traditional handicrafts like the manufacture of walking sticks and the weaving of textiles while aiding preservation of local culture and providing a new source of income for local communities (PDO, 2007a). Other PDO projects that empower organisations and communities to sustain themselves include the Local Community Contractors (LCC) initiative that provides local people in the concession areas to 
become entrepreneurs and possibly PDO contractors (PDO, 2007a). Training programmes and opportunities that foster financial empowerment and sustainability to organisations and communities are shared in common with countries like Nigeria with a strong Shell presence (Eweje, 2006) and in Poland (Szczepanski et al., 2009).

During 2008 PDO signed Memoranda of Understanding (MOUs) with 13 government ministries and local non-government organisations (NGOs) covering 17 different Social Investment (SI) projects (Shell, 2008a). These SI projects encompass the following areas;

- construction of water treatment plants to provide clean water supplies for local communities;

- provision of a new health centre as well as a maternity ward (to address the issue of mothers dying at childbirth or from complications related to it);

- provision of 'smart classrooms' to 12 schools nation-wide;

- supply of four mobile laboratories in south Oman;

- provision of sunshades to 12 schools all over Oman to facilitate outside play during the hot summer;

- support for the Al Noor Association for the Blind in a major project aimed at restoring sight to blind Omani children;

- purchase of 24 special seats for children by the Early Intervention Association;

- two separate training programmes to improve communities' economic self-sufficiency support for the Ministry of Manpower's supply of 'training for employment' programmes, and support for the Ministry of Social Development's special training in the production and marketing of milk products;

- assistance to the Ministry of Fisheries to improve beaching areas for fishing boats;

- drilling of a water supply well for a local golf course;

- payment for the installation of street lighting thereby improving communities' lifestyle and safety;

- support of the second stage of the Central Oman Palaeolithic survey;

- support of a project to minimize litter along the Muscat coastline.

As to the general welfare of Omani society and employees, health and safety concerns in PDO are addressed systematically as part of core business strategy (PDO, 2007a). The award winning Integrated Impact Assessments (IIA) strategic tool is used for identifying and assessing the potential environmental, social and health impacts of a proposed project, evaluate alternatives, and design appropriate mitigation/enhancement management and monitoring measures (CSRwire.com, 2007a; PDO, 2007a; Shell, 2007). There is a Traffic Safety Institute donated in 2005 to the nation as part of the Gift to the Nation tradition by the corporation to demonstrate its commitment to driver safety nationally, for example (PDO, 2005).

On sustaining the environment, PDO has engaged in a massive clean-up operation of a blowout, and is aiming at a safe and responsible well-abandonment campaign (PDO, 2007a). It proceeded with its policy of minimising its carbon footprint and increasing its energy efficiency (PDO, 2007). To do this it is collecting waste heat from the power plants at its thermal Enhanced Oil Recovery (EOR) projects in heat-recovery units and recycling it for steam production (PDO, 2007a). This set up is being established at other fields, and is estimated to yield a total emissions 
saving of over 4 million tons of $\mathrm{CO}_{2}$ per year within five years (PDO, 2007a). PDO is the first oil company in the Middle East to gain ISO 14001 certification for its environmental management systems (CSRwire, 2007b). Water management is an issue as Oman has limited natural fresh water resources (CIA, 2007). Shell and PDO are working on technologies aimed increasing efficiency in operational usage and recycling of wastewater for agricultural use (CSR Europe, 2006). This approach to water management has been fully integrated in Oman's national water management plan and resulted in its selection as an example for best practice sharing in the oil industry’s ‘Water Management Good Practice Guidelines’ (CSR Europe, 2006).

\section{Theoretical / Managerial Implications}

This study adds to the body of literature on CSR theory, in particular its international understanding. There is still need for a standardised definition of the concept that businesses in society could focus on making profit, paying taxes, and providing employment, all these in ways that set higher ethical standards, going beyond what is required by law". The results of this exploratory research study show that Omani society, including Omanis and resident expatriates, expect corporations to provide 'safe products/services', appropriately treat employees, provide 'reliable products/services', behave ethically, and be 'committed to social responsibility' above all else out of sixteen attributes depicting an ideal socially responsible company. These are not generally core CSR aspects, but relate more to corporate sustainability as often defined by transnational and multinational corporations (MNCs). Practitioners can plan their CSR strategies to reflect these findings.

\section{Limitations and recommendations}

This research paper focuses on CSR practice of two companies in just two industry sectors - the extractive and construction industry, based on published information in the public domain. Research (Knox et al., 2005) indicates that the potential for bias in such business-provided public information justifies investigating such reports. Furthermore, the telecommunications and banking sectors in Oman embark on charity drives individually or in partnership with other citizens, also corporate ones, during Ramadan prior to the Eid celebrations to collect and donate to the less privileged in society, in particular children. During 2010, they have extended their highly publicized CSR activities for children to include seasons outside of the traditional Ramadan period (Oman Daily Observer, 2010a). A study investigating CSR practice in these two major industry sectors in Oman is recommended. Such a study could contrast CSR practice across all major industry sectors (extractive transnationals joint venture partners versus the telecommunications and banking sectors) in Oman. A more extensive study of CSR practice within the various Oman-based SMEs is also recommended. The limited number of respondents to the Minnee (2007) CSR study suggests that its findings are generalizable only to them. That study occurred during the Muslim Holy Month of Ramadan. A follow up study in Oman conducted outside of the Muslim Holy Month of Ramadan is advisable.

\section{Conclusion}

In practice, oil and gas transnational corporations working as joint venture partners with the Omani government, tend to systematically incorporate philanthropy with strategic concerns for the economic, social, and environmental issues and impacts of their operations primarily where they operate and also the greater community. Their strategic social initiatives are in education, 
training, health and environment. The goal is corporate sustainability although they invariably contribute to socio-economic developments in the communities where they operate. This conforms to findings from studies on CSR in emerging market economies where MNCs and TNCs are perceived as partners for socio-economic development. CSR (and SD) is depicted as being socially embedded and a function of socio-cultural and socio-economic factors (Amaeshi $e t$ al., 2006; Steurer et al, 2005).

Oman is an Islamic country where philanthropy is expected, in particular during the Holy Month of Ramadan. The Telecommunications and Banking sectors in Oman embark on charity drives individually or in partnership with other citizens, also corporate ones, during Ramadan prior to the Eid celebrations to collect and donate to the less privileged in society, in particular children. Some small and medium enterprises (SMEs) voluntarily practice philanthropy alongside more core CSR activities, but not systematically as part of an integrated primarily corporate-benefitting strategy. This evidence also aligns with findings on the CSR philosophy and practices of small and medium enterprises in some transitional economies. There is a need to increase the level of awareness of and the practice of CSR beyond mostly seasonal non-strategic charitable donations via the education of the greater business community in Oman. Future research can focus on exploring the small and medium enterprise sectors as well as service industry sectors such as telecommunications and banking.

\section{References}

Abdulnabi Macki, A. bin (2007), "Driving Investment," Oman Economic Review, Vol. 79, February, pp. 27-30.

Amaeshi, K., Bongo, M., Adi, C., Ogbechie, C. and Amao, O. O. (2006), "Corporate Social Responsibility in Nigeria: Western Mimicry or Indigenous Influences", The Journal of Corporate Citizenship, Vol. 24, pp. 83-99.

Bank Muscat, Omantel donate painting kits to kids in Royal Hospital. Oman Daily Observer a, (June 27, 2010: 22).

Brady, A. (2005), "Notes from Romania: CR in Central and Eastern Europe", Corporate Responsibility Management, Vol. 2, No. 2. pp. 10-11.

Chamber Oman (2002), "Doing business in Oman," available at: http://www.chamberoman.com/doing-occi-economy.asp (accessed 25 June 2007).

Central Intelligence Agency (CIA) (2007), "The World Fact Book - Oman", available at: https://www.cia.gov (accessed 5 July 2008).

CSR Europe (2006), "Shell reducing water use and wastewater footprint in Oman", available at: http://www.csreurope.org (accessed May 2007).

CSRwire.com (2007a), "Shell and PDO's Integrated Impact Assessment (IIA) process", available at: http://www.csrwire.com (accessed May 2007). 
CSRwire.com (2007b), "PDO's ISO 14001 certification", available at: http://www.csrwire.com (accessed May 2007).

Das, S. C. (2009), "Status and direction of corporate social responsibility in Indian perspective: an exploratory study", Social Responsibility Journal, Vol. 5, No. 1, pp. 34-47.

De Schutter, O. (2008), “Corporate Social Responsibility European Style”, European Law Journal, Vol. 14, No. 2, pp. 203-236.

Donaldson, T. and Preston, L.E. (1995), "The Stakeholder Theory of the Corporation: Concepts, Evidence, and Implications", Academy of Management Review, Vol. 20, No. 1, pp. 65-91.

Environics International (now Globescan), (1999), "The Millennium Poll on Corporate Social Responsibility," available at: http://www.ipsos-mori.com (accessed 6 June 2007).

Eweje, G. (2006), "The Role of MNEs in Community Development Initiatives in Developing Countries: Corporate Social Responsibility at Work in Nigeria and South Africa," Business and Society, Vol. 45, No. 2, pp. 93-129.

Freeman, R.E. (1984), Strategic Management: A stakeholder Approach. Boston: Pitman/Ballinger.

Friedman, M. and Friedman, M. (1962), Capitalism and Freedom. Chicago: University of Chicago Press.

Globescan (formerly Environics International) (2001), "Corporate Social Monitor 2001: Global Public Opinion on the Changing Role of Companies," available at: www.globescan.com (accessed 6 June 2007).

GolinHarris (2005), "The State of Corporate Citizenship 2005 - Doing Well by Doing Good 2005: The Trajectory of Corporate Citizenship in American Business," available at: http://www.volunteermatch.org . (accessed 6 June 2007).

Halfway to Vision 2020 (2007), Oman Economic Review, 79, (February), 8.

Imbun, B. Y. (2007), "Cannot Manage without the 'Significant Other': Mining, Corporate Social Responsibility and Local Communities in Papua New Guinea", Journal of Business Ethics, Vol. 73, pp. 177-192.

Jamali, D. and Mirshak, R. (2007), "Corporate Social Responsibility (CSR): Theory and Practice in a Developing Country Context," Journal of Business Ethics, Vol. 72, pp. 243-262.

Jose, L. 2008. "A different take", Business Today. September, available at: http://www.businesstoday.com/archive (accessed 30 August 2009).

Koladkiewicz, I. (2009), "Corporate social responsibility in Poland: the Responsible Business 
Forum 2002-2007 report perspective”, Social Responsibility Journal, Vol. 5, No. 1, pp. 34-47.

Knox, S., Maklan, S. and French, P. (2005), Corporate Social Responsibility: Exploring Stakeholder Relationships and Programme Reporting across Leading FTSE Companies. Journal of Business Ethics Vol. 61: 20. available at: http://www.curtin.edu.au (accessed 23 June 2007).

Malhotra, N.K., Hall, J., Shaw, M. and Crisp, M. (1996), Marketing Research: An Applied Orientation. Sydney: Prentice Hall Australia Pty Ltd.

McWilliams, A., Siegel, D.S. and Wright, P.M. (2006), "Corporate Social Responsibility: Strategic Implications”,Journal of Management Studies, Vol. 43, No.1, pp. 1-18.

Ministry of Information, Sultanate of Oman. (2004), "Oman 2003-2004: Economic Development”, available at: http://www.omanet.om (accessed 22 August 2007).

Minnee, F. (2007), Corporate Social Responsibility (CSR)/Corporate Citizenship (CC) in 2007 Oman Survey Report.

Mohan, A. (2006), "Global Corporate Social Responsibilities Management in MNCs", Journal of Business Strategies, Vol. 23, No.1. pp. 1-31.

Oppenheim J., Bonini, S., Bielak, D., Kehm, T., and Lacy, P. (2007) 'Shaping the New Rules of Competition: UN Global Compact Participant Mirror', available at: www.unglobalcompact.org (accessed 23 August 2007).

Petroleum Development Oman (PDO), (2007a), Petroleum Development Oman Annual Report 2007 to His Majesty Sultan Qaboos bin Said, Sultan of Oman: People. Partnership. Progress.

Petroleum Development Oman (PDO), (2007b), 'PDO: then and now', An Manhal: a fount of knowledge, Vol. 7. p. 18.

Petroleum Development Oman (PDO), (2005), 'Partner to Development - PDO Social Performance - 2005', available at: http://www.pdo.co.om . (accessed 22 August 2007).

Roberts, S, Keeble, J. and Brown, D. (2007), "The Business Case for Corporate Citizenship," available at: http://www.weforum.org (accessed 8 July 2007).

Royal Dutch Shell PLC Annual Report and Form 20-F for the year ended December 31, 2008, Shell (2008b).

Royal Dutch Shell PLC Sustainability Review 2008, Shell, (2008c), available at: http://www.shell.com/home (accessed 22 August 2007).

Royal Dutch Shell PLC. Shell, (2007c), available at: http://www.shell.com/home , (accessed 5 July 2007). 
Shanka, T., Minnee, F. and Taylor, R. (2008), "Important Attributes of Corporate Social Responsibility - an exploratory assessment from Oman". 1-3 December. Proceedings of the Australian and New Zealand Marketing Academy Conference, Sydney, Australia, available at: http://www.anzmac.org . (accessed September 2009).

Shell, (2008a), PDO signs record number of Social Investment MOUs', Shell In the Middle East (42): 22.

Shell in Oman - Social Investment Guidelines, Shell d, (2009). available at: http://www.shell.com/home . (accessed 1 September 2009).

Steurer, R., Langer, M.E., Konrad, A. and Martinuzzi, A. (2005), "Corporations, stakeholders and sustainable development I: a theoretical exploration of business-society relations", Journal of Business Ethics, Vol. 61, pp. 263-281.

Sudman, S. (1980), "Improving the quality of shopping center sampling". Journal of Marketing Research, Vol. 17, pp. 423-431.

Szczepanski, M.S., Geisler, R. and Sliz, A. (2009), "Building a model of corporate social responsibility in the old industrial region (in the case of Upper Silesia): a sociological perspective", Social Responsibility Journal, Vol. 5, No. 1, pp. 34-47.

Tan, W. (2005), "In the next decade how can more businesses and other organisations in Australia be positively encouraged to implement corporate social responsibility practices? Prime Minister's Business Partnership's Corporate Social Responsibility Essay Competition 2005 available at: http://www.facs.gov.au or http://facsia.gov.au or http://partnerships.gov.au . (accessed 1 June 2007).

Toky, Majid al (2007), “Accelerating Growth”, Oman Economic Review, Vol. 79 (February), pp. 31-32.

Trebeck. K. (2008), "Exploring the responsiveness of companies: corporate social responsibility to stakeholders", Social Responsibility Journal, Vol. 4, No. 3, pp. 349-365.

Whitehouse, L. (2006), "Corporate Social Responsibility: Views from the Frontline," Journal of Business Ethics, Vol. 63, No.3. pp. 279-296. available at: http://www.curtin.edu.au (accessed 23 June 2007).

'Women career development programme organised'. Oman Daily Observer b (accessed 15 August 2009).

Wulfson, M. (2001), "The Ethics of Corporate Social Responsibility and Philanthropic Ventures", Journal of Business Ethics, Vol. 29, pp. 135-145.

Zinkin, J. (2007), "Islam and CSR: a study of the compatibility between the tenets of Islam, the UN Global Compact and the development of social, human and natural capital", Corporate Social Responsibility and Environmental Management, Vol. 14, No.4, pp. 206-218. 


\section{APPENDIX 1}

\section{Origins of the Minnee (2007) Research questions}

\begin{tabular}{|c|c|c|}
\hline & Research questions & Sources \\
\hline Screening question & $\begin{array}{l}\text { RQ } 1 \text { Do you know about Corporate Social } \\
\text { Responsibility /Corporate Citizenship? }\end{array}$ & \\
\hline $\begin{array}{l}\text { Most relevant factor } \\
\text { (CSR and non- } \\
\text { CSR) considered } \\
\text { when forming } \\
\text { impressions of a } \\
\text { company }\end{array}$ & $\begin{array}{l}\text { RQ } 2 \text { Here is a list of factors said to determine } \\
\text { how consumers form impressions of a company. } \\
\text { (SHOW CARD 1) Could you go down the list and } \\
\text { for each factor tell me how important it is to } \\
\text { you when forming impressions of a company. }\end{array}$ & $\begin{array}{l}\text { Globescan, } 2001 \text { and } \\
\text { Environics International, } \\
1999\end{array}$ \\
\hline $\begin{array}{l}\text { Consumers/public } \\
\text { expectations of a } \\
\text { company's role in } \\
\text { society }\end{array}$ & $\begin{array}{l}\text { RQ } 3 \text { Here is a list of what is said are or should } \\
\text { be a company's role in society. (SHOW CARD } \\
\text { 2). Could you go down the list and for } \\
\text { each statement tell me how much you agree or } \\
\text { disagree about what the role of a company in } \\
\text { society should be }\end{array}$ & $\begin{array}{l}\text { Globescan, } 2001 \text { and } \\
\text { Environics International, } \\
1999\end{array}$ \\
\hline $\begin{array}{l}\text { Attributes of a good } \\
\text { corporate } \\
\text { citizen/socially } \\
\text { responsible } \\
\text { company }\end{array}$ & $\begin{array}{l}\text { RQ } 4 \text { Here is a list of attributes of what people } \\
\text { consider/expect a good Corporate Citizen / a } \\
\text { Socially Responsible Company to have. (SHOW } \\
\text { CARD 3) Could you go down the list and for } \\
\text { each attribute tell me how important you } \\
\text { consider each attribute to be when you rate a } \\
\text { company for Corporate Citizenship/Social } \\
\text { Responsibility. }\end{array}$ & Farris, 2005 \\
\hline $\begin{array}{l}\text { Consumer } \\
\text { behaviour toward } \\
\text { socially } \\
\text { irresponsible } \\
\text { companies }\end{array}$ & $\begin{array}{l}\text { RQ } 5 \text { Based on your perception of a company } \\
\text { as socially responsible or a good Corporate } \\
\text { Citizen how often have you considered taking } \\
\text { any of the following actions (SHOW CARD 4) in } \\
\text { the last year. }\end{array}$ & $\begin{array}{l}\text { Globescan, } 2001 \text { and } \\
\text { Environics International, } \\
1999\end{array}$ \\
\hline $\begin{array}{l}\text { Main source for } \\
\text { information about a } \\
\text { company's CC/CSR }\end{array}$ & $\begin{array}{l}\text { RQ } 6 \text { Which of the communication media on this } \\
\text { list (SHOW CARD 5) is your main source for } \\
\text { information about a company's Corporate } \\
\text { Citizenship/Corporate Social Responsibility. }\end{array}$ & $\begin{array}{l}\text { Fleishman- } \\
\text { Hillard/National } \\
\text { Consumers League, } \\
2007 \text {, and GolinHarris, } \\
2005\end{array}$ \\
\hline Gender & RQ 7 Is the respondent male or female? & \\
\hline Age & $\begin{array}{l}\text { RQ } 8 \text { Which of these age groups do you belong } \\
\text { to? (SHOW CARD 6). }\end{array}$ & \\
\hline Education & $\begin{array}{l}\text { RQ 9 Which of these options best describes your } \\
\text { educational background (SHOW CARD 7)? }\end{array}$ & \\
\hline Nationality & $\begin{array}{l}\text { RQ } 10 \text { Are you Omani or Expatriate? (SHOW } \\
\text { CARD 8). }\end{array}$ & \\
\hline Continent of origin & $\begin{array}{l}\text { RQ } 11 \text { Which geographic region do you come } \\
\text { from? (SHOW CARD 9) }\end{array}$ & \\
\hline
\end{tabular}




\section{Appendix 2}

\section{CARD No. 3}

RQ 4. Here is a list of attributes of what people consider/expect a good Corporate Citizen / a Socially Responsible Company to have. (SHOW CARD 3) Could you go down the list and for each attribute tell me how important you consider each attribute to be when you rate a company for Corporate Citizenship/Social Responsibility.

(CIRCLE ONE NUMBER)

\begin{tabular}{|c|c|c|c|c|c|}
\hline Attribute & $\begin{array}{c}\text { Not } \\
\text { Important }\end{array}$ & $\begin{array}{r}\text { Moderately } \\
\text { Important }\end{array}$ & Important & $\begin{array}{c}\text { Very } \\
\text { Important }\end{array}$ & $\begin{array}{l}\text { Critically } \\
\text { Important }\end{array}$ \\
\hline Treats its employees fairly & 1 & 2 & 3 & 4 & 5 \\
\hline $\begin{array}{l}\text { Acts in an ethically responsible } \\
\text { manner }\end{array}$ & 1 & 2 & 3 & 4 & 5 \\
\hline $\begin{array}{ll}\text { Provides } & \text { reliable } \\
\text { products/services } & \end{array}$ & 1 & 2 & 3 & 4 & 5 \\
\hline Provides safe products/services & 1 & 2 & 3 & 4 & 5 \\
\hline $\begin{array}{l}\text { Responsibly markets its products/ } \\
\text { services }\end{array}$ & 1 & 2 & 3 & 4 & 5 \\
\hline Committed to social responsibility & 1 & 2 & 3 & 4 & 5 \\
\hline $\begin{array}{lll}\text { Committed } & \text { to } & \text { economic } \\
\text { opportunity }\end{array}$ & 1 & 2 & 3 & 4 & 5 \\
\hline $\begin{array}{l}\text { Committed to environmental } \\
\text { protection }\end{array}$ & 1 & 2 & 3 & 4 & 5 \\
\hline Committed to workforce diversity & 1 & 2 & 3 & 4 & 5 \\
\hline $\begin{array}{l}\text { Engages the community in local } \\
\text { business decisions }\end{array}$ & 1 & 2 & 3 & 4 & 5 \\
\hline $\begin{array}{l}\text { Is actively involved in the } \\
\text { communities } \\
\text { business }\end{array}$ & 1 & 2 & 3 & 4 & 5 \\
\hline $\begin{array}{ll}\text { Products/services } & \text { enhance } \\
\text { peoples' lives } & \end{array}$ & 1 & 2 & 3 & 4 & 5 \\
\hline $\begin{array}{l}\text { Corporate values are aligned with } \\
\text { those of society }\end{array}$ & 1 & 2 & 3 & 4 & 5 \\
\hline $\begin{array}{l}\text { Donates/invests fair share of } \\
\text { profits to benefit others }\end{array}$ & 1 & 2 & 3 & 4 & 5 \\
\hline $\begin{array}{l}\text { Donates/invests good/services to } \\
\text { benefit others }\end{array}$ & 1 & 2 & 3 & 4 & 5 \\
\hline $\begin{array}{l}\text { Supports a cause/issue leading to } \\
\text { social good }\end{array}$ & 1 & 2 & 3 & 4 & 5 \\
\hline
\end{tabular}

